\title{
Sequenciamento de Sanger
}

(6) By Editor-in-chief

14 de maio de 2021

Sequenciamento de primeira geração: método de Sanger

Fernanda Stussi D Lage (D), Fenícia Brito (D)

Revisão: Diego Mariano (D)

BIOINFO - Revista Brasileira de Bioinformática. Edição \#01. Julho, 2021.

DOI: 10.51780/978-6-599-275326-03

este artigo, as autoras apresentam uma breve descrição do método de sequenciamento de primeira geração proposto Frederick Sanger e colaboradores em 1977. O método de Sanger foi revolucionário para biologia, sendo considerado um dos primeiros métodos amplamente adotados para identificação de sequências de DNA. Boa leitura!

\section{Introdução}

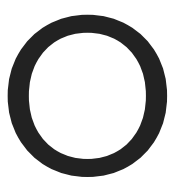

termo Bioinformática apareceu pela primeira vez na década

de 1970, em um artigo de Paulien Hogeweg e Ben Hesper. Eles a definiram como: "o estudo de processos informáticos em sistemas bióticos" [6]. Nesse estudo, os autores abordaram os processos de informática em sistemas bióticos em várias escalas [7]. Mais do que isso, nessa década houve avanços nos métodos de biologia molecular que permitiram uma manipulação mais fácil do ácido desoxirribonucleico (DNA). A clonagem de genes e a PCR (Polymerase Chain Reaction, de forma traduzida "reação em cadeia da polimerase") eram agora comumente usadas na preparação de bibliotecas de DNA [1]. Naquela época, surgiam computadores cada vez mais miniaturizados e mais poderosos (antes da década de 1970, um 'minicomputador' tinha razoavelmente as dimensões e o peso de um pequeno refrigerador doméstico). Além disso, cada vez mais surgiam novos softwares mais adequados para lidar com tarefas de bioinformática [4]. Esse contexto propiciou o surgimento de abordagens de sequenciamento de nucleotídeos, que pode ser resumido como "a determinação da ordem dos ácidos nucléicos em determinada amostra biológica" [5].

As primeiras abordagens foram baseadas no método químico de degradação de cadeia de Maxam-Gilbert, que permitiu o sequenciamento de 24 pares de bases. Posteriormente, o método de terminação de cadeia desenvolvido por Frederick Sanger permitiu o sequenciamento do primeiro genoma completo: o Fago $\Phi \times 174$ com o total de 5375 bases [2]. 


\section{O método de Sanger}

O método de Sanger, como assim ficou conhecido, também denominado método didesoxi, é a base da primeira geração de sequenciadores. Ele se baseia no uso de uma enzima DNA polimerase para sintetizar cadeias de DNA de comprimentos variados. Nesse método, uma fita de DNA servirá como molde para fita da qual deseja-se descobrir a sequência. Tome como exemplo a sequência abaixo:

\section{5' AGCTTCAGTC 3'}

Figura 1 - Exemplo de uma sequência de nucleotídeos a ser sequenciada. Fonte: figura adaptada de [9].

Assim, os componentes necessários para uma reação de sequenciamento de Sanger são (Figura 2):

1. A molécula de DNA que se deseja conhecer a sequência (DNA molde);

2. Todos os quatro tipos de nucleotídeos, também chamados de dNTPs (desoxinucleotídeos), sendo cada um, separado em um tubo distinto de reação, ou seja, um tubo para Adenina (dATP), outro para Timina (dTTP), outro para Citosina (dCTP) e por fim, outro para Guanina (dGTP);

3. Didesoxinucleotídeos, um tipo especial de nucleotídeos também chamados de ddNTPs (sendo respectivamente denominados ddATP, ddCTP, ddGTP e ddTTP para se referirem a didesoxinucleotídeos de Adenina, Citosina, Guanina e Timina). Esses nucleotídeos especiais são similares aos nucleotídeos comuns, mas com uma diferença chave: falta um grupo hidroxila na posição $3^{\prime}$ do carbono do anel de sacarose. Em um nucleotídeo comum, o grupo 3' hidroxila atua como um "gancho", permitindo que um novo nucleotídeo seja adicionado à cadeia existente. Uma vez que um didesoxinucleotídeo é adicionado à cadeia, não há hidroxila disponível e nenhum outro nucleotídeo pode ser adicionado, ou seja, é um nucleotídeo que uma vez incorporado, interrompe a ação da polimerase e assim termina a cadeia que está sendo sintetizada;

4. Sequência iniciadora (primer);

5. Enzima polimerase.

Fita a ser sequenciada de DNA:

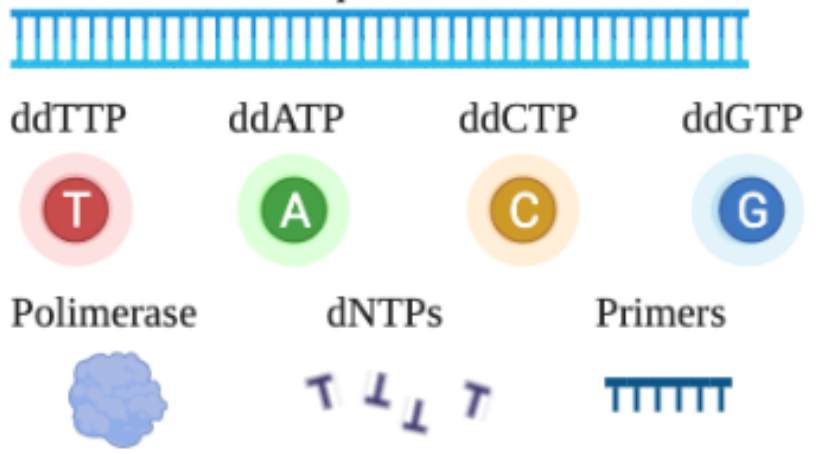


Figura 2. Componentes necessários para a realização do sequenciamento de Sanger. Fonte: figura adaptada de: <Biorender.com>. Acesso em: 04 de abril de 2021.

Para que o sequenciamento ocorra, uma sequência iniciadora com algumas dezenas de pares de base de nucleotídeos, denominada primer, é projetada para ser o ponto de partida. Durante a reação, o primer liga-se a uma região complementar na sequência do DNA alvo, servindo como ponto de partida para a síntese de uma nova fita. A enzima DNA polimerase é responsável por adicionar novos nucleotídeos à fita de DNA em crescimento, partindo da sequência primer (Figura 3).

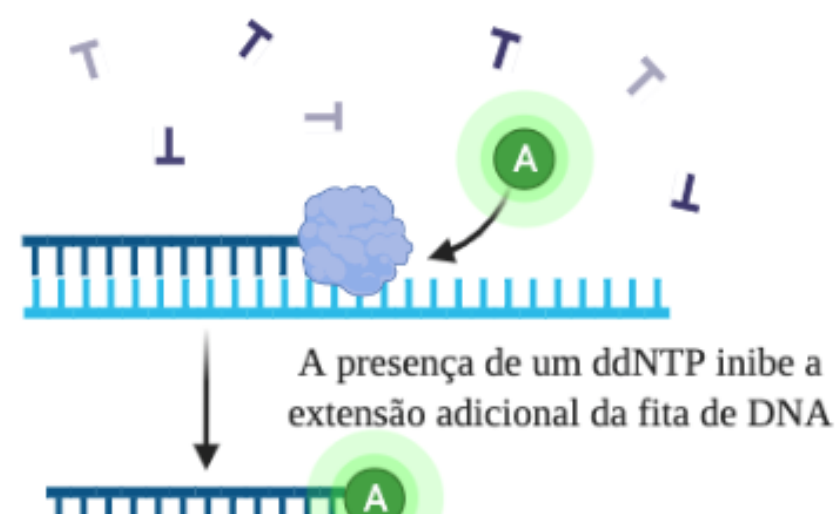

Figura 3. Exemplo do que ocorre em um tubo de reação quando apenas o didesoxinucleotídeo ddATP foi adicionado. Fonte: figura adaptada de: <Biorender.com>. Acesso em: 04 de abril de 2021.

Além disso, uma grande quantidade de cada um dos quatro nucleotídeos normais ( $A, C, G$ e T - respectivamente Adenina, Citosina, Guanina e Timina) são adicionados separadamente ao DNA a ser sequenciado, que é então dividido em quatro tubos de reação (Figura 4A). Cada um desses tubos recebe uma pequena quantidade de didesoxinucleotídeos trifosfatos (ddNTPs): ddATP, ddGTP, ddCTP ou ddTTP. Como dito anteriormente, os didesoxinucleotídeos diferenciam-se dos nucleotídeos comuns pela ausência da hidroxila (OH) no carbono 3' (Figura 4B). Como esses didesoxinucleotídeos serão incorporadas apenas ocasionalmente, cada reação produz um conjunto de cópias de DNA que terminam em diferentes pontos da sequência. Após a síntese, os produtos das reações A, G, C e T são carregados individualmente em quatro faixas de um único gel e separados por eletroforese em gel, um método que separa os fragmentos de DNA por seus tamanhos. A sequência de DNA da fita recém-sintetizada pode ser determinada lendo as bandas em ordem, começando no fundo do gel. Uma vez que cada cópia tem uma letra a mais que a última, pode-se classificar as cadeias de DNA por tamanho e usar as sequências das bandas para a leitura da fita (Figura 4). 


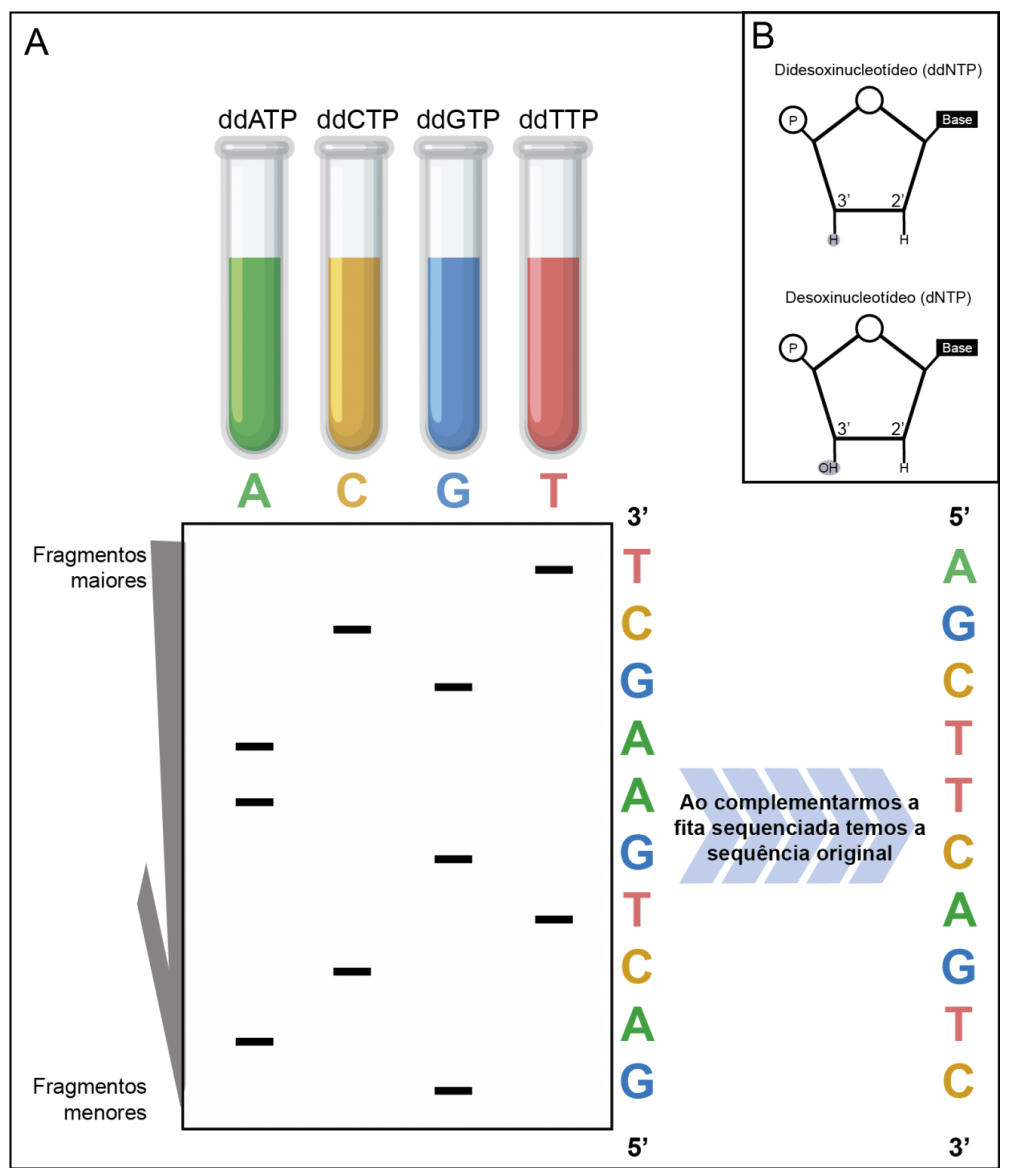

Figura 4. Esquema geral do sequenciamento de Sanger. (A) A reação de sequenciamento acontece em tubos contendo cada tipo de ddNTP e todos os demais componentes. Após a reação, o conteúdo resultante é lido em uma corrida de eletroforese em gel que separa os fragmentos sequenciados por tamanho. Lendo a coluna do gel pode-se recuperar a ordem em que os ddNTPs foram adicionados e assim recuperar a sequência original. (B) Diferença entre os didesoxinucleotídeos e os desoxinucleotídeos. Fonte: figura adaptada de [9].

\section{Exemplo}

Para ilustrar como funciona o processo de sequenciamento de Sanger, vamos demonstrar como a sequência-exemplo AGCTTCAGTC seria sequenciada. A banda que se encontra na posição mais inferior do gel é a que contém o menor fragmento sequenciado. Supostamente esse fragmento contém apenas o primer e o primeiro nucleotídeo da sequência. Começamos olhando para os menores fragmentos. Conforme observado na Figura 4, se em todas as quatro faixas a banda de gel aparecer na faixa de reação $G$, o primeiro nucleotídeo na sequência será $G$. Então, se a próxima banda aparecer na faixa $A$, o segundo nucleotídeo na sequência será $A$, e assim por diante $[1,3$, 8]. Dessa forma, sucessivamente identificaríamos os nucleotídeos da sequência, conforme o tamanho dos diferentes fragmentos. Conforme pode ser observado na Figura 5, vemos que os diferentes fragmentos da nossa sequência-exemplo são ordenados por tamanho. 


\title{
5' AGCTTCAGTC 3'
}

\author{
G 5' \\ A G 5' \\ $C A G 5^{\prime}$ \\ TCAG 5' \\ GTCAG 5' \\ AGTCAG 5' \\ AAGTCAG 5' \\ GAAGTCAG 5' \\ CGAAGTCAG 5' \\ TCGAAGTCAG 5'
}

Figura 5. Exemplos de fragmentos de DNA de tamanho

diferentes gerados nos tubos com didesoxinucleotídeos durante o sequenciamento. Fonte: figura adaptada de [9].

\section{Conclusão}

Essa metodologia de sequenciamento foi tão inovadora que levou o cientista Frederick Sanger a receber o Prêmio Nobel de Química em 1980. Nas décadas seguintes, os avanços técnicos automatizaram, aceleraram drasticamente e refinaram ainda mais o processo de sequenciamento de Sanger. Essas automatizações do método de Sanger foram essenciais para a conclusão de várias etapas do Projeto Genoma Humano em 2001 [2]. Esse método, ficou conhecido como Sequenciamento de Primeira Geração, em contraste aos métodos mais novos, desenvolvidos desde 2005, que tornaram o sequenciamento do genoma ainda mais rápido - e muito mais barato. Esses novos métodos de sequenciamento, denominados de segunda geração, foram responsáveis pela diminuição drástica do custo do sequenciamento de DNA [1]. Tendo como consequência o "boom" do número de genomas sequenciados que vemos atualmente.

\section{Referências}


[1] ALBERTS, Bruce et al. Molecular Biology of the Cell. 6. ed. Nova York: Garland Science, Taylor \& Francis Group, Llc, 2015. 1465 p.

[2] CHIAL, H. DNA sequencing technologies key to the Human Genome Project. Nature Education 1(1):219, 2018. Disponivel em:

<https://www.nature.com/scitable/topicpage/dna-sequencing-technologieskey-to-the-human-828/\#TB_inline?

height $=300 \&$ width $=400 \&$ inlineld=trOutLine . Acesso em: 04 de abril de 2021 .

[3] DNA Sequencing. Scitable by Nature Educations. Disponível em: https://www.nature.com/scitable/definition/dna-sequencing-205/>. Acesso em 24 de abril de 2020.

[4] GAUTHIER, J. et al. A brief history of bioinformatics. Briefings in Bioinformatics, v. 20, n. 6, p. 1981-1996, 27 nov. 2019.

[5] HEATHER, James M.; CHAIN, Benjamin. The sequence of sequencers: the history of sequencing dna. Genomics, [S.L.], v. 107, n. 1, p. 1-8, jan. 2016. Elsevier BV. http://dx.doi.org/10.1016/j.ygeno.2015.11.003.

[6] HOGEWEG, P.; HESPER, B. Interactive instruction on population interactions. Computers in Biology and Medicine, v. 8, n. 4, p. 319-327, jan. 1978.

[7] HOGEWEG, P. The Roots of Bioinformatics in Theoretical Biology. PLos Computational Biology, v. 7, n. 3, p. el002021, 31 mar. 2011

[8] NGUYEN, Tien. The race to sequence the human genome. TedEd. Disponivel em: <https://ed.ted.com/lessons/the-race-to-sequence-the-humangenome-tien-nguyen\#digdeeper >. Acesso em 24 de abril de 2020.

[9] XINGZHAO WEN, SHENG ZHONG. 3D Genome from technology to visualization. Disponível em: <https://zhonglab.gitbook.io/3dgenome/chap0preparation/0.2-sequencing-technologies〉. Acesso em: 04 de abril de 2021. 